\title{
PENGARUH KEEFEKTIFAN PENGENDALIAN INTERNAL KETAATAN ATURAN AKUNTANSI TERHADAP KECENDERUNGAN KECURANGAN AKUNTANSI PADA BANK CIMB NIAGA
}

\author{
Viola Syukrina E Janrosl ${ }^{1}$, Septenus Zembua ${ }^{2}$ \\ Program Studi Akuntansi \\ Universitas Putera Batam \\ E-mail: Viola.myudzz21@gmail.com
}

\begin{abstract}
Abstrak
Riset ini bertujuan untuk mengetahui hubungan efektivitas pengendalian internal atas ketaatan aturan akuntansi atas kecenderungan kecurangan akuntansi. Kecurangan akuntansi merugikan pemegang saham dan investor. Secara umum pengendalian internal sangat diperlukan dalam kegiatan entitas bisnis. Populasi yang digunakan dalam penelitian ini adalah karyawan Bank CIMB Niaga dan level manager yaitu Senior Brand Manajer, Brand Manager, Relatioship Manager CIMB Preffecd, Relationship Manager, Brand Operation Service Manager, dan Service Manager. Penelitian ini menggunakan sampel jenuh yang mana semua populasi akan dijadikan sampel. Teknik analisa data yang digunakan analisis regresi linier berganda, uji T dan uji $\mathrm{F}$ yang nantinya data riset ini akan diolah menggunakan SPSS versi 21. Hasil penelitian ini ketaatan aturan akuntansi berpengaruh signifikan terhadap kecenderungan kecurangan akuntansi. Keefektifan pengendalian internal berpengaruh signifikan terhadap kecenderungan kecurangan akuntansi. Keefektifan pengendalian internal dan ketaatan aturan akuntansi berpengaruh signifikan terhadap kecenderungan kecurangan akuntansi sebesar 55,2\%. Sedangkan sisanya 44,8\% dipengaruhi oleh variabel lain yang tidak diteliti.

Kata Kunci: Keefektifan Pengendalian Internal, Ketaatan Aturan Akuntansi, Kecenderungan Kecurangan Akuntansi
\end{abstract}

\begin{abstract}
This research aims to determine the relationship between the effectiveness of internal control over compliance with accounting rules for accounting fraud. Accounting fraud is detrimental to shareholders and investors. In general, internal control is very necessary in the activities of business entities. The population used in this study are Bank CIMB Niaga employees and level managers, namely Senior Brand Managers, Brand Managers, CIMB Preffect Relationship Managers, Relationship Managers, Brand Operations Service Managers, and Service Managers. This study uses a saturated sample in which all populations will be sampled. Data analysis techniques used multiple linear regression analysis, $T$ test and $F$ test which later this research data will be processed using SPSS version 21. The results of this research observance of accounting rules significantly influence the tendency of accounting fraud. The effectiveness of internal control significantly influences the tendency of accounting fraud. The effectiveness of internal control and compliance with accounting rules significantly influence the tendency of accounting fraud by 55.2\%. While the remaining $44.8 \%$ is influenced by other variables not
\end{abstract}


examined.

Keywords: Effectiveness of Internal Control, Compliance with Accounting Rules, Tendency to Accounting Fraud

\section{Pendahuluan}

Kecurangan akuntansi merugikan pemegang saham dan investor.Secara umum pengendalian internal sangat diperlukan dalam kegiatan entitas bisnis. Pemantauan pengendalian internal diperlukan mendelegasikan wewnang dan tanggung jawab suatu organisasi. Internal control sebagai serangkaian tindakan yang mencakup seluruh proses dan personel organisasi untuk memberikan jaminan yang masuk akal tentang 3 tujuan yaitu keefektifan dan efisisensi operasi serta keandalan pelaporan keuangan. Jika suatu organisasi tidak memiliki control internal yang efektif ada kemungkinan bahwa laporan keuangan organisasi terindikasi kecurangan (Rizki \& Anisykurlillah, 2018).

Kasus kecurangan akuntansi terjadi pada PT BPR Multi Artha Mas Sejahtera dimana Otoritas Jasa Keuangan mengungkapkan terjadi penyelewengan dana nasabah senilai 6,28 miliar oleh komisaris PT BPR Multi Artha Mas Sejahtera dimana dana digunakan untuk kepentingan pribadi. Tindakan korupsi ini sangan merugikan entitas perusahaan (Fauzie, 2018).

Korupsi adalah suatu tindakan yang dapat terjadi karena ada suatu tekanan, adanya peluang dan rasa rasionalisasi. Fenomenanya kasus korupsi ini ada yang berupa kasus suap, kepentingan diri sendiri dan memalsukan tanda terima serta kasus pemerasan. Dampak dari perbuatan ini sangat merugikan pihak internal dan eksternal perusahaan (Gabryela \& Butar, 2017).

Keluhan (Shelvy, 2017) kasus terjadi pada Bank CIMB Niaga yang mengecewakan nasabah pelanggan kartu kredit. Berawal dari notifikasi transaksi kartu kredit melalui email SGD 612.40 dan SGD 0.00 dari transaksi Travel Reservation dan $\mathrm{Rp}$ 7.053.280 di Hotel.com. Karena merasa tidak melakukan transaksi tersebut nasabah melakukan konfirmasi ke pihak bank. Dari total transaksi di atas nasabah ditagih setengah dari total transaksi di atas. Dari kasus diatas terindikasi ada kecurangan akuntansi. Karena kurangnya pengedalian internal dari bank.

Upaya untuk mencegah dan memelihara aset berwujud perusahaan yang terdiri dari karyawan, komputer, kas maupun aset yang tidak berwujud seperti hak cipta maka sangat diperlukan pengendalian internal agar tidak merugikan pihak internal yaitu pemilik perusahaan dan pihak eksternal yaitu nasabah dan investor perusahaan.

Setiap manajemen perusahaan seharusnya menerapkan aturan akuntansi pada entitasnya masing-masing karena publik memerlukan kapabiliti kebenaran dari suatu informasi. Aturan akuntansi yang benar seperti membuat laporan keuangan berdasarkan standar akuntansi IFRS, melaporkan laporan keuangan tepat waktu adalah salah satu upaya untuk meaningkatkan kapabiliti dari suatu informasi akuntansi bisa (Ratri \& Kusumastuti, 2012).

Beberapa permasalahan yang terjadi saat ini membuat penulis tertarik untuk mengangkat topic riset mengenai Kecenderungan Kecurangan Akuntansi Pada Bank CIMB Niaga Batam.

\section{Kajian Literatur \\ Kecurangan Akuntansi}

Kecurangan Akuntansi dapat didefenisikan suatu tindakan diperbuat suatu 
individu atau team dengan maksud yang tidak baik yang dapat merugikan orang banyak (Thoyibatun, 2012). Antara penyelewengan dan kekeliruan mempunyai perbedaan yaitu dari tindakan yang mendasarinya, yang menyebabkan terjadi penyelewengan laporan keuangan, berkelakuan yang berencana atau tidak direncanakan terjadi. Kekeliruan yang terjadi di dalam laporan keuangan mempunyai 2 tipe yaitu kekeliruan pelaporan keuangan dan kekeliruan akibat perlakuan penggelapan aset perusahaan (Meliany \& Hernawati, 2012).

Kecurangan akuntansi yaitu kekeliruan yang terjadi akibat kecurangan dalam pelaporan keuangan, salah saji yang diakibatkan manipulasi laporan keuangan secara sengaja, baik manipulasi jumlah atau pengungkapan yang merugikan pengguna laporan keuangan yaitu pihak internal dan eksternal (Rahmawati, 2012).

Indikator dari kecurangan akuntansi menurut (Rahmawati, 2012) ialah:

1. Keinginan untuk melakukan kecurangan, pembajakan dan manipulasi catatan akuntansi.

2. Keinginan untuk melakukan kesalahan penyampaian data atau peghilangan peristiwa, transaksi, atau informasi yang signifikan dari laporan keuangan.

3. Melakukan kesalahan secara sengaja dalam menggunakan prinsip akuntansi.

4. Salah saji dalam menyajikan laporan keuangan yang disebabkan penggelapan atas aset sehingga megakibatkan perusahaan melunasi barang atau jasa tidak diakui.

5. Kesalahan yang diakibatkan perlagaan yang tidak wajar pada aktiva dan pemalsuan dokumen.

\section{Keefektifan Pengendalian Internal}

Pengendalian Internal yaitu suatu prosedur yang dilaksanakan brtujuan menjamin bahwa yang diinginkan perusahaan terwujud dan untuk meminimalisir kerugian terjadi kegagalan dalam berita.

Pengendalian Internal merupakan alur yang dibuat untuk memberikan keyakinan memadai capaian tujuan manajemen. Beberapa faktor yang menyebabkan pengendalian internal meliputi integritas, nilai etika, filosofi dan gaya operasi manajemen (Meliany \& Hernawati, 2012).

Indikator dari keefektifan pengendalian internal menurut (Rahmawati, 2012) yaitu:

1. Lingkungan Pengendalian

2. Penilaian Resiko

3. Aktivitas Pengendalian

4. Informasi dan Komunikasi

5. Pemantauan

\section{Ketaatan Aturan Akuntansi}

Ketaatan aturan akuntansi adalah kewajiban dalam organisasi karena jika laporan keuangan dibuat tidak mengikuti aturan akuntansi dapat menyebabkan peluang terjadinya prilaku tidak etis serta kecurangan akuntansi. Setiap perusahaan go public harus membuat laporan keuangan berdasarkan aturan yang dibuat didalam standar akuntansi IFRS (Internasional Financial Reporting Standar). Informasi dari laporan keuangan sangat dibutuhkan oleh pihak internal seperti manajer, karyawan dan pemilik perusahaan dan pihak eksternal yaitu investor dan kreditor (Shintadevi, 2015).

Indikator dari ketaaatan aturan akuntansi yaitu:

1. Tanggung Jawab

2. Implementasi

3. Kepentingan Publik 
4. Integritas

5. Objektivitas

\section{Metode Penelitian}

Desain penelitian merupakan kerangka kerja yang digunakan dalam suatu penelitian. Desain penelitian yang digunakan dalam penelitian ini adalah desain penelitian eksploratif dan deskriptif. Tujuan penelitian eksploratif yaitu menyelidiki suatu masalah agar didapatkan suatu pemahaman. Sedangkan penelitian deskriptif memiliki pertanyaan yang jelas mengenai permasalahan yang dihadapi, hipotesis yang spesifik dan informasi yang detail yang dibutuhkan.

\section{Lokasi Penelitian}

Lokasi Penelitian dalam penelitian ini akan dilakukan Bank CIMB Niaga Tbk Jl Laksamana Bintan, Sei Panas, Komplek Executive Center Blok 1 No 1 ABC.

\section{Populasi dan Sampel}

Populasi yang digunakan dalam penelitian ini adalah karyawan Bank CIMB Niaga dan level manager yaitu Senior Brand Manajer, Brand Manager, Relatioship Manager CIMB Preffecd, Relationship Manager, Brand Operation Service Manager, dan Service Manager. Penelitian ini menggunakan sampel jenuh yang mana semua populasi akan dijadikan sampel.

\section{Variabel Penelitian}

1. Kecurangan Akuntansi

Kecurangan akuntansi yaitu salah saji yang timbul akibat terjadinya kecurangan dalam pelaporan keuangan, salah saji yang diakibatkan manipulasi laporan keuangan secara sengaja, baik manipulasi jumlah atau pengungkapan yang merugikan pengguna laporan keuangan yaitu pihak internal dan eksternal (Rahmawati, 2012).

Indikator dari kecurangan akuntansi menurut (Rahmawati, 2012) ialah: a. Keinginan untuk melakukan kecurangan, pembajakan dan manipulasi catatan akuntansi.

b. Keinginan untuk melakukan kesalahan penyampaian data atau peghilangan peristiwa, transaksi, atau informasi yang signifikan dari laporan keuangan.

c. Melakukan kesalahan secara sengaja dalam menggunakan prinsip akuntansi.

d. Salah saji dalam menyajikan laporan keuangan yang disebabkan penggelapan atas aset sehingga megakibatkan perusahaan melunasi barang atau jasa tidak diakui.

e. Kesalahan yang diakibatkan perlagaan yang tidak wajar pada aktiva dan pemalsuan dokumen.

2. Keefektifan Pengendalian Internal Pengendalian Internal merupakan alur yang dibuat untuk memberikan keyakinan memadai capaian tujuan manajemen. Beberapa faktor yang menyebabkan pengendalian internal meliputi integritas, nilai etika, filosofi dan gaya operasi manajemen (Meliany \& Hernawati, 2012).

Indikator dari keefektifan pengendalian internal menurut (Rahmawati, 2012) yaitu:

a. Lingkungan Pengendalian

b. Penilaian Resiko

c. Aktivitas Pengendalian

d. Informasi dan Komunikasi

e. Pemantauan

3. Ketaatan Aturan Akuntansi

Ketaatan aturan akuntansi adalah kewajiban dalam organisasi karena jika laporan keuangan dibuat tidak mengikuti aturan akuntansi dapat 
menyebabkan peluang terjadinya prilaku tidak etis serta kecurangan akuntansi. Setiap perusahaan go public harus membuat laporan keuangan berdasarkan aturan yang dibuat didalam standar akuntansi IFRS (Internasional Financial Reporting Standar). Informasi dari laporan keuangan sangat dibutuhkan oleh pihak internal seperti manajer, karyawan dan pemilik perusahaan dan pihak eksternal yaitu investor dan kreditor (Shintadevi, 2015).

Indikator dari ketaaatan aturan akuntansi yaitu:
a. Tanggung jawab
b. Implementasi
c. Kepentingan publik
d. Integritas
e. Objektivitas

\section{Teknik Pengumpulan Data}

Penelitian ini adalah penelitian kuantitatif. Instrumen yang digunakan dalam penelitian ini adalah dengan memyebarkan kuisioner kepada karyawan Bank CIMB Niaga dan level manager yaitu Senior Brand Manajer, Brand Manager, Relatioship Manager CIMB Preffecd, Relationship Manager, Brand Operation Service Manager, dan Service Manager. Jawaban dari responden nantinya akan diukur menggunakan skala likert

\section{Model Penelitian}

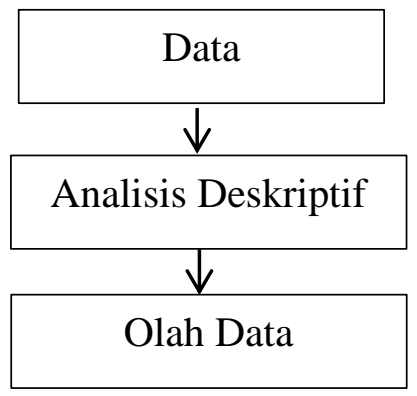

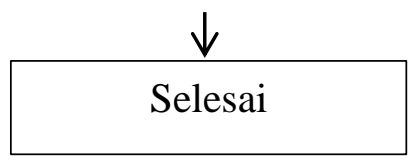

Sumber :Penulis (2019).

Gambar 1 Model Penelitian

Berdasarkan model penelitian diatas dapat dilihat tahap pertama menyebarkan kuisioner kepada karyawan Bank CIMB Niaga Batam yang nantinya menggunakan skala likert. Setelah itu tabulasi data akan di olah dengan menggunakan software SPSS.

\section{Hasil dan Pembahasan Hasil Penelitian}

Hasil penelitian merupakan ringkasan dari informasi yang diperoleh dari data dan disajikan dari bentuk analisis deskriptif, uji validitas, pengujian reabilitas dan uji regresi linear berganda.

\section{Profil Responden}

Data penelitian dikumpulkan dengan cara menyebarkan 60 kuesioner kepada karyawan Bank CIMB Niaga dan level manager.

Sebagai proses awal analisis dalam hasil penelitian ini, dilakukan analisis terhadap profil dari para responden, berdasarkan kuesioner yang telah dikumpulkan oleh peneliti, maka data jumlah responden dapat dikategorikan berdasarkan jenis kelamin,umur, semester, dan lama usaha. Berikut ini profil dari responden berdasarkan kuesioner yang dikumpulkan.

\section{Demografi Responden}

Hasil uji deskripsi responden berdasarkan jenis kelamin dalam penelitian ini disajikan dalam tabel 4.1 berikut ini: 
Tabel 1

Data Responden Berdasarkan Jenis

Kelamin

Descriptive Statistics

\begin{tabular}{|c|c|c|c|c|}
\hline & $\mathrm{N}$ & $\begin{array}{c}\text { Minimu } \\
\mathrm{m}\end{array}$ & $\begin{array}{c}\text { Maxim } \\
\text { um }\end{array}$ & Mean \\
\hline $\begin{array}{l}\text { LAKI_LAK } \\
\text { I }\end{array}$ & 35 & 1.00 & 1.00 & 1.0000 \\
\hline $\begin{array}{l}\text { PEREMPU } \\
\text { AN } \\
\text { Valid N } \\
\text { (listwise) }\end{array}$ & 60 & 2.00 & 2.00 & 2.0000 \\
\hline
\end{tabular}

Sumber: Data diolah, SPSS 21, 2019

Berdasarkan tabel 1 diatas menunjukkan bahwa mayoritas level manager pada Bank CIMB Niaga batam pada penelitian ini adalah berjenis kelamin laki-laki yaitu sebesar 35 orang atau sekitar $35 \%$ sisanya sebesar 25 orang atau sekitar $25 \%$ berjenis kelamin perempuan.

Hasil Uji t (Persial)
Digunakan untuk mengetahui pengaruh variabel independen atau bebas (X) terhadap variabel dependen atau terikat (Y). Hipotesis dalam pengujian ini, sebagai berikut:

$\mathbf{H}_{1}=$ Variabel $\mathrm{X} 1$ berpengaruh terhadap variabel $\mathrm{Y}$.

$\mathbf{H}_{2}=$ Variabel $\mathrm{X} 2$ berpengaruh terhadap variabel Y

Kaidah pengambilan keputusan dalam pengujian ini adalah:

1. Jika $\mathbf{t}$ hitung $>\mathbf{t}$ tabel dan nilai Signifikan $<0,05$, maka $\mathbf{H}_{\mathbf{1}}$ diterima, jadi variabel independen (X) berpengaruh signifikan terhadap variabel dependen (Y).

2. Jika $\mathbf{t}$ hitung $<\mathbf{t}$ tabel dan nilai Signifikan >0,05, maka $\mathbf{H}_{2}$ ditolak, jadi variabel independen (X) tidak berpengaruh signifikan terhadap variabel dependen (Y).

Tabel 2. Hasil (Uji t)

\begin{tabular}{lccccc}
\multicolumn{6}{c}{ Coefficients $^{\mathrm{a}}$} \\
\hline Model & \multicolumn{2}{c}{$\begin{array}{l}\text { Unstandardize } \\
\text { d Coefficients }\end{array}$} & $\begin{array}{c}\text { Standardized } \\
\text { Coefficients }\end{array}$ & T & Sig. \\
& B & $\begin{array}{c}\text { Std. } \\
\text { Error }\end{array}$ & Beta & & \\
\hline & & & & \\
\hline $\begin{array}{l}\text { Constant) } \\
\text { Keefektifan }\end{array}$ & 2.455 & 1.673 & & 1.467 & .148 \\
$\begin{array}{l}\text { Pengendalian } \\
\text { Internal }\end{array}$ & .062 & .059 & .124 & 1.041 & .302 \\
$\begin{array}{l}\text { Ketaatan } \\
\text { Aturan } \\
\text { Akuntansi }\end{array}$ & .348 & .063 & .654 & 5.494 & .000
\end{tabular}

Dari tabel 2 diatas dapat dilihat hasil uji t hitung, sehingga dibandingkan dengan $t$ table:

1. Pengaruh keefektifan pengendalian internal $\left(\mathrm{X}_{1}\right)$ terhadap kecenderungan kecurangan akuntansi (Y). Hasil perhitungan untuk nilai signifikan $0.302>0,05$ dan $t$ hitung $1.041<2.00247$ Jadi keefektifan pengendalian internal 
$\left(\mathrm{X}_{1}\right)$ tidak berpengaruh signifikan terhadap kecenderungan kecurangan akuntansi (Y). Hal ini mengandung implikasi bahwa sebaiknya Bank CIMB Niaga terus meningkatkan keefektifan pengendalian Internal yang telah ada agar tujuan perusahaan yang telah direncanakan dapat tercapai dan kecurangan akuntansi yang mungkin dapat terjadi dapat diminimalisir.

Penelitian ini konsisten dengan penelitian yang dilakukan (Shintadevi, 2015) yang menyatakan bahwa ketaatan aturan akuntansi berpengaruh secara signifikan terhadap kecenderungan kecurangan akuntansi.

2. Pengaruh ketaatan aturan akuntansi $\quad\left(\mathrm{X}_{2}\right) \quad$ terhadap kecenderungan kecurangan akuntansi (Y). Hasil perhitungan untuk nilai signifikan $0.00<0,05$. Jadi ketaatan aturan akuntansi $\left(\mathrm{X}_{2}\right)$ berpengaruh signifikan terhadap kecenderungan kecurangan akuntansi (Y). Hal ini mengandung implikasi bahwa Bank CIMB Niaga dalam menyusun dan menyajikan, baik Laporan
Keuangan maupun Laporan Kinerja sesuai dengan aturan akuntansi. Perusahaan tetap harus terus meningkatkan Ketaatan Aturan Akuntansi dalam menyusun dan menyajikan, baik Laporan Keuangan maupun Laporan Kinerja. Semakin tinggi tingkat Ketaatan Aturan Akuntansi dalam menyusun dan menyajikan Laporan Keuangan serta Laporan Kinerja, maka dapat mengurangi peluang untuk melakukan Kecurangan Akuntansi.

Penelitian ini konsisten dengan penelitian yang dilakukan Penelitian ini konsisten dengan penelitian yang dilakukan (Shintadevi, 2015) yang menyatakan bahwa keefektefian pengendalian internal berpengaruh secara signifikan terhadap kecenderungan kecurangan akuntansi.

\section{Hasil Uji F (simultan)}

Pengujian ini dilakukan untuk mengetahui apakah semua variabel independen $\left(\mathrm{X}_{1}, \mathrm{X}_{2}, \mathrm{X}_{3}\right.$ dan $\left.\mathrm{X}_{4}\right)$ yang dimasukkan dalam model memiliki pengaruh secara bersama-sama terhadap variabel dependen.

Tabel 3 Hasil Uji F

ANOVA $^{a}$

\begin{tabular}{rlrrrrr}
\hline Model & & $\begin{array}{c}\text { Sum of } \\
\text { Squares }\end{array}$ & Df & \multicolumn{1}{c}{$\begin{array}{c}\text { Mean } \\
\text { Square }\end{array}$} & F & Sig. \\
\hline \multirow{3}{*}{1} & Regression & 333.636 & 2 & 166.818 & 35.146 & $.000^{\mathrm{b}}$ \\
& Residual & 270.547 & 57 & 4.746 & & \\
& Total & 604.183 & 59 & & & \\
\hline
\end{tabular}

a. Dependent Variable: Kecenderungan Kecurangan Akuntansi

b. Predictors: (Constant), Ketaatan Aturan Akuntansi, Keefektifan

Pengendalian Internal

Berdasarkan tabel perhitungan diatas diperoleh nilai signifikan $0,000<0,05$ dan $\mathrm{f}$ hitung $35.146>3.16$ yang menunjukkan secara simultan keefektifan pengendalian internal dan ketaatan aturan akuntansi

berpengaruh secara signifikan terhadap kecenderungan kecurangan akuntansi (Y).

Penelitian ini konsisten dengan penelitian yang dilakukan (Fitri, 2016) yaitu kesesuaian kompensasi berhubungan 
negative terhadap kecenderungan kecurangan akuntansi dan ketaatan aturan akuntansi juga mempengaruhi kecenderungan kecurangan akuntansi.secara negative

\section{Hasil Uji R Square}

Menurut Wibowo (2012: 135) analisis ini digunakan dalam hubungan untuk mengetahui jumlah atau persentase sumbangan pengaruh variabel bebas dalam model regresi yang secara serentak atau bersama-sama memberikan pengaruh terhadap variabel bebas. Hasil nilai $\mathrm{R}$ dapat dilihat ditabel dibawah ini :

Tabel 5 Hasil Uji R dan R Square Model Summary ${ }^{\mathrm{b}}$

\begin{tabular}{lcccr}
\hline Model & $\mathrm{R}$ & $\mathrm{R}$ Square & $\begin{array}{c}\text { Adjusted } \mathrm{R} \\
\text { Square }\end{array}$ & Std. Error of the Estimate \\
\hline 1 & $.743^{\mathrm{a}}$ & .552 & .536 & 2.17863 \\
\hline $\begin{array}{l}\text { a. Predictors: (Constant), Ketaatan Aturan Akuntansi, Keefektifan Pengendalian } \\
\text { Internal } \\
\text { b. Dependent Variable: Kecenderungan Kecurangan Akuntansi }\end{array}$
\end{tabular}

Berdasarkan hasil perhitungan diperoleh bahwa $R$ square $\left(R^{2}\right)=0,552$ dapat disimpulkan bahwa keefektifan pengendalian internal dan ketaatan aturan akuntansi berpengaruh signifikan terhadap kecenderungan kecurangan akuntansi sebesar $55,2 \%$. Sedangkan sisanya $44,8 \%$ dipengaruhi oleh variabel lain yang tidak diteliti.

\section{Simpulan}

Berdasarkan hasil penelitian dan pembahasan yang telah diuraikan, maka penulis menarik kesimpulan adalah sebagai berikut:

1. Ketaatan aturan akuntansi berpengaruh signifikan terhadap kecenderungan kecurangan akuntansi pada Bank CIMB Niaga.

2. Keefektifan pengendalian internal berpengaruh signifikan terhadap kecenderungan kecurangan akuntansi Bank CIMB Niaga.

3. Keefektifan pengendalian internal dan ketaatan aturan akuntansi berpengaruh signifikan terhadap kecurangan akuntansi Bank CIMB Niaga sebesar 55,2\%. Sedangkan sisanya $44,8 \%$ dipengaruhi oleh variabel lain yang tidak diteliti.

\section{Saran}

Berdasarkan hasil penelitian penulis mengusulkan saran-saran yang kiranya bermanfaat bagi pihak-pihak yang terkait dalam penelitian yaitu:

1. Diharapkan peneliti selanjutnya dapat memperluas lokasi penelitian misalnya semua peerbankan di Kota Batam

2. Diharapkan untuk peneliti selanjutnya agar dapat menambah variabel lain yang mempengaruhi kecenderungan kecurangan akuntansi

3. Diharapkan peneliti selanjutnya menggunakan metode penelitian lain seperti wawancara dan observasi sehingga dapat meningkatkan kualitas data yang telah diperoleh. 


\section{DAFTAR PUSTAKA}

Chen, Y. jen, \& Chen, Y. M. (2018). Fraud detection for financial statements of business group. International Journal of Accounting Information Systems.

Fauzie, Y. Y. (2018). OJK Ungkap Penyelewengan Dana Nasabah Bank Multi Artha.

Fitri, Y. (2016). Pengaruh Keefektifan Sistem Pengendalian Internal, Ketaatan Akuntansi, Asimteri Akuntansi Dan Moralitas Individu Terhadap Kecendrungan Kecurangan Akuntansi dengan Perilaku Tidak Etis Sebagai Variabel Intervening. JOM Fekon, 3.

Gabryela, S., \& Butar, A. (2017). Penerapan Skeptisisme Profesional Auditor Internal Pemerintah Dalam Mendeteksi Kecurangan, 20(1), 169-188.

Ghozali, I. (2011). Aplikasi Analisis Multivariate dengan Program IBM SPSS 19. Semarang: Badan Penerbit Universitas Diponegoro.

McCallig, J., Robb, A., \& Rohde, F. (2019). Establishing the representational faithfulness of financial accounting information using multiparty security, network analysis and a blockchain. International Journal of Accounting Information Systems.

Meliany, L., \& Hernawati, E. (2012). Pengaruh Keefektifan Pengendalian Internal dan Kesesuaian Kompensasi Terhadap Kecenderungan Kecurangan Akuntansi.

Rahmawati, A. P. (2012). Analisi Pengaruh Faktor Internal Dan Kecenderungan Kecurangan Akuntansi.

Ratri, N., \& Kusumastuti. (2012). Analisis Faktor-Faktor Yang Berpengaruh Terhadap Kecenderungan Kecurangan Akuntansi Dengan Perilaku Tidak Etis Sebagai Variabel Intervening.

Rizki, P., \& Anisykurlillah, I. (2018). The Determinant of Internal Control
Effectiveness on Cooperative Employees of the Republic of Indonesia in Semarang City, 7(1), 7886.

https://doi.org/10.15294/aaj.v5i3.19346

Sekyi, E. K. A., \& Gene, J. M. (2017). Internal Controls and Credit Risk Relationship Among Bank in Europe. Intangible Capital, 13.

Shelvy. (2017). Ada Transaksi Fraud Kecewa Solusi yang Diberikan CIMB Niaga.

Shintadevi, P. F. (2015). Pengaruh Keefektifan Pengendalian Internal, Ketaatan Aturan Akuntansi Dan Kesesuaian Kompensasi Terhadap Kecenderungan Kecurangan Akuntansi Dengan Perilaku Tidak Etis Sebagai Variabel Intervening. Nominal, $I V$.

Sugiyono. (2015). Metode Penelitian Kuantitatif,Kualitatif dan $R \quad \& \quad D$. Bandung.

Thoyibatun, S. (2012). Faktor Faktor Yang Berpengaruh Terhadap Perilaku Tidak Etis Dan Kecenderungan Kecurangan Akuntansi Serta Akibatnya Terhadap Kinerja Organisasi. Ekuitas Jurnal Ekonomi Dan Keuangan, (110). 